\title{
Vulval leiomyoma: a rare clinical entity
}

\section{Amudha P.*, Kalarani E., Karthika Devi A., Swathi M.}

Department of Obstetrics \& Gynaecology, Thanjavur Medical College, Thanjavur, Tamil Nadu, India

Received: 09 February 2016

Accepted: 05 March 2016

\section{*Correspondence:}

Dr. Amudha P.,

E-mail: amudha70dr@gmail.com

Copyright: () the author(s), publisher and licensee Medip Academy. This is an open-access article distributed under the terms of the Creative Commons Attribution Non-Commercial License, which permits unrestricted non-commercial use, distribution, and reproduction in any medium, provided the original work is properly cited.

\section{ABSTRACT}

Vulval leiomyomas are rare benign tumors which arise from the smooth muscle cells within erectile tissue, blood vessel walls or round ligament remnants in labium majus. As they are rare, clinical diagnosis is often challenging. We report a case of 64 year old postmenopausal woman with a labial swelling of 3 months duration. It was clinically diagnosed as Bartholin`s gland cyst and intraoperatively the gross appearance was that of a leiomyoma and surgical excision was performed. Histopathological analysis confirmed the diagnosis of leiomyoma.

Keywords: Vulval leiomyoma, Extrauterine leiomyoma, Vulval tumor

\section{INTRODUCTION}

Leiomyomas are benign smooth muscle tumors and by far are the commonest gynecologic neoplasms. Symptomatic uterine leiomyomas affect $20-30 \%$ of women older than 35 years. ${ }^{1,2}$ However vulval leiomyomas are a rarity and are mostly seen in the $5^{\text {th }}$ and $6^{\text {th }}$ decades of life. ${ }^{3}$

Vulval leiomyomas are believed to arise from the smooth muscle cells within the erectile tissue, blood vessels or the round ligament remnants in the labium majus. ${ }^{4}$ Other unusual sites of origin in the genitourinary tract include the ovaries, urethra and urinary bladder. ${ }^{5}$ Leiomyomas in the unusual locations as in vulva make their clinical identification challenging and pose diagnostic dilemma. Histopathologic analysis is required to confirm the diagnosis.

\section{CASE REPORT}

Mrs. R, a 64 year old obese, postmenopausal woman presented with a painful swelling in the vulva of 3 months duration. Her general, physical and systemic examination was unremarkable. On examination of her external genitalia, she was found to have a non- tender, tense cystic mass of about $5 \times 4 \mathrm{cms}$ in the lower part of left labium majus. The vulval lesion was clinically diagnosed as Bartholin's gland cyst and marsupialisation was planned.

Intra-operatively the lesion was solid and in a slightly deeper plane (Figure 1). It was enucleated with ease and was sent for histopathological examination. Tissue defect was obliterated after securing hemostasis. On gross examination, the enucleated mass was firm, greyish white and measured $5 \times 4 \times 3 \mathrm{~cm}$. On cut section (Figure 2), it had the characteristic whorled appearance of a leiomyoma. Histopathological examination revealed spindle cells in hyaline stroma and confirmed that it indeed was a leiomyoma. Her post-operative period was uneventful. She was followed up after 6 weeks and was asymptomatic.

\section{DISCUSSION}

The uterus is the most common site of origin of leiomyomas; however they may arise at any site where smooth muscle cells are found. Rarely extrauterine leiomyomas may be seen along the labium majus. Only a few hundreds of vulval leiomyomas have been reported in literature. ${ }^{5}$ 


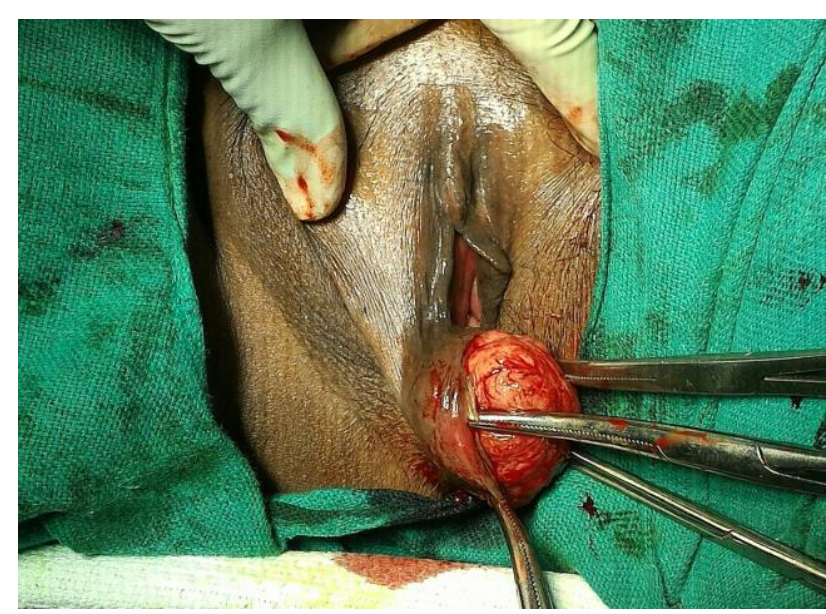

Figure 1: Intraoperative appearance of Vulval leiomyoma.

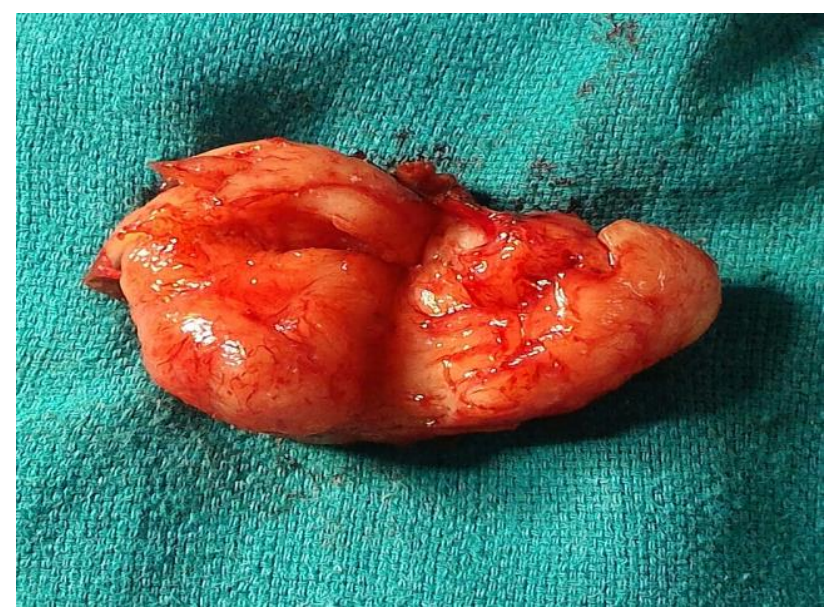

Figure 2: Cut section of Vulval leiomyoma.

The mean age of presentation of these tumors varies from 13 to 71 years and in our case the woman was 64 yrs and postmenopausal. The average size of the tumor ranged from 0.5 to $15 \mathrm{~cm} .^{6}$ Vulval leiomyomas are usually asymptomatic, present as painless lumps and most often are misdiagnosed as Bartholin's gland cyst as in our case. $^{7,8}$ The differential diagnosis include benign and malignant entities such as Bartholin's gland cyst, fibromas, lymphangiomas, soft tissue sarcomas, neurogenic tumors and Epstein Barr virus induced smooth muscle tumors. 5,9

Although these tumors are almost always benign, it is essential to distinguish these from malignant tumors that may have a close clinical resemblance. Confirmatory diagnosis is by histopathological analysis. Neilson et al proposed that vulval tumors which fulfil the following criteria should be considered malignant:

1. Diameter greater than $5 \mathrm{cms}$ and infiltrative margins.

2. More than 10 mitotic figures/10 HPF

3. Moderate to severe cellular atypia. ${ }^{7}$
The tumors frequently test positive for estrogen and progesterone receptors at histopathological analysis. ${ }^{5}$ Degenerative changes in these tumors have also been reported. $^{10,11}$

Vulval leiomyomas are treated with conservative surgery. Close long term follow-up is required as these tumors can recur even in postmenopausal women mimicking vulval carcinoma. $^{6,12,13}$

Funding: No funding sources

Conflict of interest: None declared

Ethical approval: Not required

\section{REFERENCES}

1. Szklaruk J, Tamm EP, Choi H, Varavithya V. MR imaging of common and uncommon large pelvic masses. RadioGraphics. 2003;23(2):403-24

2. ButtramVC Jr, Reiter RC. Uterine leiomyomata: etiology, symptomatology, and management. Fertil Steril. 1981;36(4):433-45

3. Guardiola MT, Dobin SM, Dal Cin P, Donner LR. Pericentric inversion (12) (p12q13-14) as the sole chromosomal abnormality in a leiomyoma of the vulva. Cancer Genet Cytogenet. 2010;199(1):21-3.

4. Kaufmanm RH, Gardner HL. Benign mesodermal tumors. Clin Obstet Gynecol. 1965;8(4):953-81

5. Fasih N, Parsad Shanbhogue AK, Macdonald DB, Fraser-Hill MA, Papadatos D, Kielar AZ. Leiomyomas beyond the uterus: unusual location rare manifestations. Radiographics. 2008;28:193148.

6. Nielsen GP, Rosenberg AE, Koerner FC, Young RH, Scully RE. Smooth-muscle tumors of the vulva: a clinicopathological study of 25 cases and review of the literature. Am J Surg Pathol. 1996;20(7):779-93.

7. Al Azzam M, Orrell JM, Vasey DP. Vulval leiomyoma with a myxoid hyaline stroma. J Obstet Gynaecol. 2004;24(8):936.

8. Murat ÖZ, Bülent KÖSTÜ, Emre ÖZGÜ. Leiomyoma of the vulva. The Journal of Gynecology - Obstetrics and Neonatology. 2013:1594-5.

9. Khunamornpong S, Sukpan K, Suprasert P, Shuangshoti S, Pintong J, Siriaunkgul S. EpsteinBarr virus-associated smooth muscle tumor presenting as a vulvar mass in an acquired immunodeficiency syndrome patient: a case report. Int J Gynecol Cancer. 2007;17(6):1333-7.

10. Aguilera Martinez V, Perez Santana ME, Avila Contreras ML, Mendoza E. Vulvar leiomyoma. Report of a case. Ginecol Obstet Mex. 2011;79:3825.

11. Zhou J, Ha BK, Schubeck D, Chung-Park M. Myxoidepithelioid leiomyoma of the vulva: a case report. Gynecol Oncol. 2006;103:342-5.

12. Gonzalez-Bugatto F, Anon-Requena MJ, LopezGurrero MA, Baez-Perea JM, Bartha JL, HerviasVivancos B. Vulvar leiomyosarcoma in Bartholin's 
gland area: a case report and literature review. Arch Gynecol Obstet. 2009;279:171-4.

13. Guven S, Esinler D, Salman MC, Gultekin M, Ayhan A. Recurrent vulval leiomyoma in postmenopausal patient mimicking vulval carcinoma. Journal of obstetrics and gynecology: the journal of the Institute of obstetrics and gynecology. 2005;25:7:732-5.
Cite this article as: Amudha $\mathrm{P}$, Kalarani E, Karthika Devi A, Swathi M. Vulval leiomyoma: a rare clinical entity. Int J Reprod Contracept Obstet Gynecol 2016;5:1254-6. 